Indonesian Journal of EFL and Linguistics

Vol. 4 No. 1, 2019

eISSN: 2503-4197, pISSN: 2527-5070

www. indonesian-efl-journal.org

\title{
Speech Acts in the Selected and Award Winning Filipino Children Short Stories
}

\author{
Frances Mae Serenio \\ University of San Carlos, Philipine \\ email: sakura_041888@yahoo.com \\ Cindy Velasquez \\ University of San Carlos, Philiphine \\ email: cavelasquez@usc.edu.ph
}

\begin{abstract}
:
Children's literature may be one of the most difficult genres to write, if not the most difficult. The writer has to take into consideration his or her aims in writing the story while focusing on other literary elements such as the theme and the plot at the same time. Not only that, he or she has to put in mind what kind of reaction he wants from his or her reader - whether it be amusement, rejection or wholesome acceptance through learning. The purpose of this study is to identify the different speech acts commonly found in contemporary children's short stories particularly those which have been awarded as Palanca winners and those from the book entitled Filipino Stories for Filipino children (An Anthology from the UP Integrated School Creative Writing Classes) by Eleanor Eme Hermosa. The study is anchored on John Searle's (1969) Speech Act Theory. In the analysis, it is found that children's literature provides a didactic role. Consistent with this function, the speech act structure has observed didactic role found to be primarily informational, assertive, and expressive in nature. In the stories, some of the values that the writers aimed to teach the readers are nationalism, love and pride for parents and siblings, and appreciation for education.
\end{abstract}

Keywords: Filipino literature, children short stories, speech acts

Indonesian Journal of EFL and Linguistics, 4(1), 2019 
Frances Mae Serenio \& Cindy Velasquez

\section{INTRODUCTION}

Language is all around us, its use either manifested in one of two ways: the spoken and the written. Language use is seen and reflected in practice in the language teaching profession. It is typical of many such syllabi in the assumptions it makes about dividing the world of discourse: language skills and level of proficiency, listening comprehension, oral proficiency, reading comprehension, and written expression.

Written language is more evident in literature, as it is manifested as written work where it ranges from prose (where it does not adhere to any particular formal structures) to poetry (compositions written in verse). Literature can also be classified into two types: the first, being fiction (those which are not really real), and nonfiction (mostly based on real events and author's personal experiences and beliefs). It is very broad when it comes to its several forms, taking into consideration various histories and backgrounds, ranging from short stories, epics, essays, lyrics, haikus, novels and several others, even as simple as letters. Despite the wide variety of the written matter in these literary works, it is still obvious that literature mirrors language (and eventually life) in a certain creative way.

Literature, as part of language, is subject to the extensive study of its different aspects. As a type of language use, it is subject to discourse analysis or the number of approaches to analyzing written, spoken, or sign language use. Literature, despite its various forms, is undeniably still seen as written language use.

If there are various kinds of literature according to form and type, there are also kinds that pertain to the audience for which the literature is meant. Children's literature is one such example. The objective for conducting this study would be to identify the speech acts present in the children's short stories based on John Searle's (1969) speech act theory. By doing this study, linguists can specifically point out (or restate) the importance of speech acts in written discourse, but also motivate writers to improve their writing style if they wish to venture into the world of children's literature.

\section{LITERATURE REVIEW}

Specifically, on the side of the social sciences, discourses tend to be spoken of as purely ideas, notions, theories, or more generally, meanings, as if they were independent of particular symbolic forms of realization. Consequently, discourses may refer to just anything, ranging from historical documents, fashion to architecture. On the side of linguistically- oriented approaches, discourse is often taken to be formal (textual or cognitive) elements and structures, as if they were free from the researcher's interest and specific cultural context. Thus, discourses are reduced to universal forms. 
Following from the notion of discourse as contextually situated, discourse is realized through a variety of symbolic media of cultural practice (e.g. speaking/writing, media and genre). Thus, discourse may be in a written or spoken modality (though these can be intermingled, e.g. written to be spoken, spoken to be written). It may be carried in conventional or new media: e.g. the press, the radio, television, films and the world-wide-web. Needless to say, discourse is found in different genres, ranging from ordinary conversations, literature, journalism, to textbooks.

Speech act theory originated during the 1950s in the ordinary language philosophy of John Langshaw Austin and continued most notably in the work of John Searle (1969). The following discussion surveys its impact on literary studies up until 1990 (Selden 2005). Greig Henderson and Christopher Brown (1997) argued that speech act theory is a language based on Austin's (1962) How to Do Things with Words (second edition, 1975), the major premise of which is that language is as much, if not more, a mode of action as it is a means of conveying information. As Searle (1969) puts it,

All linguistic communication involves linguistic acts. The unit of linguistic communication is not, as has generally been supposed, the symbol, word, or sentence, or even the token of the symbol, word, or sentence, but rather the production or issuance of the symbol or word or sentence in the performance of a speech act.

According to Searle's (1969) basic taxonomy, there are five main categories of speech acts. (1) Assertive acts are phrases employed to form in the addressee a specific idea, proposition, or belief (e.g., "I'm sure she'll be in church today."). With assertives speakers commit themselves to something being true. (2) Directive speech acts focus on calling the addressee to action, yet do not require the sender to reciprocate any action of his own (e.g., "Wake up, wake up we're late for church"). (3) Commissives speech acts relate to committing oneself to a future action. Note that in contrast to assertive speech acts, commissives are not based in current facts (e.g., "I promised her I'd always read you a story"). (4) Expressive speech acts are based on psychological states and relate to the expression of feelings or emotions to the receiver (e.g., "Every night for three months!?"). Expressive speech acts reflect affective reactions to a situation, and therefore are not necessarily based on assertions of fact. (5) Directives speech acts.

These are the related studies about children's literature used in written discourse. In addition, the three studies are associated with literature and speech acts. Monica Bucciarelli, Livia Colle, and Bruno Bara (2003) proposed a framework for explaining difference in difficulty of various pragmatic phenomena. The study's abstract articulates that: 
Frances Mae Serenio \& Cindy Velasquez

"We propose a framework for explaining difference in difficulty of various pragmatic phenomena. In particular, we investigate the ability to comprehend direct, indirect, deceitful, and ironic communicative acts. Our main prediction is that there is a gradation of difficulty in their comprehension. Such a prediction is grounded on the assumptions that the various phenomena involve both mental representations of different complexity and different inferential load. A further prediction is that a communicative act has in principle the same difficulty of comprehension, whether performed through speech acts or communicative gestures. The underlying assumption is that the construction of the meaning of a communicative act is independent of the input modalities. We validate our predictions through an experiment on 160 children, with 40 in each of the following age groups: 2.6 to 3 years, 3.6 to 4 years, 4.6 to 5.6 years, and 6 to 7 years. The results confirm the predicted gradation of difficulty both for the different sorts of speech acts and for the communicative gestures. Also, the results, when broken down by each phenomenon, show that participants performed equally well in speech acts and in communicative gestures. We conclude with a discussion of the possible implications of our results for linguistic and gestural communication research" (Bucciarelli, Colle, and Bara, 2003).

In addition, José Angel García Landa (2007) made an extensive review and commentary of J. Hillis Miller's book Speech Acts in Literature, a major theoretical and critical book which discusses the speech act theory and practice of J. L. Austin, Jacques Derrida, Paul de Man, and Marcel Proust. Landa mentions in his study that "Hillis Miller's (2001) insights are discussed in the light of the pragmaticist theory of communicative interaction and of critical interpretation expounded. The discussion is relevant to students of linguistics and to those interested in hermeneutics, reader-response criticism and the ethics of literature and criticism" (Landa, 2007). Moreover, the author's conclusions are reasonable and logical. The way the author concluded the results truly help in different literary criticisms.

Kenneth Reeder (1988) examined the speech act comprehension of 64 three-and four-year-old subjects from a university preschool. Furthermore, the study explains that:

"Subjects were required to choose one of two paraphrases which most closely matched the pragmatic intention of a stimulus utterance. These stimulus forms were presented with puppets in a simulated preschool context previously shown to predispose children's interpretations of stimulus items toward request uptakes. Subjects were exposed to both grammatical and ungrammatical examples of a 
range of these request types. Differences in literacy experience were identified by means of a parental questionnaire. All subjects discriminated pragmatic intention significantly more reliably on grammatical items than on ungrammatical ones, but children with more extensive experiences of literacy performed poorly on the ungrammatical input, regardless of age" (Reeder, 1998).

Because of the logical presentations of speech acts and results, the ideas raised by the author are persuasive. In addition, his study was well supported.

\section{RESEARCH METHODOLOGY}

\subsection{Research Design}

This study used linguistic analysis, particularly on discourse of the selected stories. The speech act theory of Searle (1969) will be the basis for the content analysis of the said stories. The frequency of the speech acts will be determined and the functions of these speech acts as used in this kind of literature are to be identified. The researchers will also attempt to identify the underlying motives of the authors of these stories for the would-be readers.

\subsection{Research Environment}

The study was done in the University of San Carlos, most specifically in the Filipiniana Library, where the researchers photocopied an anthology of children's stories by the creative writing classes of the University of the Philippines. In addition, the researchers also got some stories from the official website of the Carlos Palanca Memorial Awards for Literature, particularly from the English short story for children Section of the said website.

\subsection{Research Instrument}

The researchers got the literary works from two sources based on two categories. The first category is the amateur type (student), where the stories come from an anthology written and compiled by the creative writing classes of the University of the Philippines. The nine stories are of academic purposes and were not entered in any known literary contests. The second category is the professional category, where the stories were winners of the Carlos Palanca Memorial Awards for Literature in the English short story for children's division. These stories were recent winners taken from the years 2006, 2007 and 2008, ranking first, second and third place from each year.

\subsection{Research Procedures}

\subsubsection{Gathering of Data}

The researchers used the stories taken from the two sources. There are sixteen stories in all, eight stories from each category. The stories in the anthology are as follows: "Isabel's Change", "Tibo's Dream", "A Call for the People", "A Knight to 
Frances Mae Serenio \& Cindy Velasquez

Remember", "Me-an's Story, Gabriela's Kiss", "I Forgive You, Bugoy", and "Ayoko." The award-winning stories are as follows: "Cut", "Big Brother", "How Rosang Taba Won a Race", "The Elusive Banana Dog", "Poor, Poor Luisa", "The Last Days of Magic", "The Storyteller and The Giant", and "The Mapangarap and The Dream Trees."

The researchers decided to take five (5) stories per category, therefore using a total of 10 stories for this study. The stories to be used in the study were randomly selected and critically studied and analyzed. The dialogues in each story were then taken out in order to facilitate easy sorting into the five categories of speech acts.

\subsubsection{Treatment of Data}

Linguistic analysis was used in identifying the speech act of the utterance. The utterances (or dialogues) are used as a basis for the analysis. Speaking lines of the characters of the different stories were lifted, classified into the different speech acts, and analyzed based on the research questions of the study. The researchers decided to present the data in tabular form, followed by an interpretation and a brief analysis, producing a more comprehensive output.

In case of cut-off statements in the dialogues as shown in examples like "Oh, sorry, I thought - ", "You can take care of - ", and "You went to sleep without a story and ", the researchers thought it best to continue the utterance as to what the speaker might have said, since there were instances where sorting of the cut-off statements was difficult unless the intended conclusion of the statements was revealed. Thus in the above examples, they could mean "Oh, sorry, I thought [that she's not having her hair cut]", "You can take care of [yourself]", and "You went to sleep without a story and [that allowed me to study]".

First, the dialogues of the stories were lifted out, broken up into individual sentences and analyzed. The researchers used tables in order to segregate and categorize the data according to speech act type. The data were presented in tabular format where the frequency of each speech act was shown. After this, analysis of the speech acts was done and inferences were drawn according to the motive or function of how each is used in the story with regard to the three approaches taken to study children's literature.

\section{FINDINGS}

Using the conversational dialogues in the selected short stories, the researchers found out that the data revealed the following illocutionary acts based on Searle's (1969) and Austin's (1962) theories. Frequency of each speech act was counted by tallying each sentence in the dialogues into a certain category. 
Speech Acts in the Selected and Award Winning Filipino Children Short Stories

Table 1. Illocutionary Speech Acts in the Palanca-winning short stories

$N=304$

\begin{tabular}{cccc}
\hline Illocutionary Acts & Frequency & Percent & Rank \\
\hline Assertives & 158 & 51.97 & 1 \\
Directives & 86 & 28.29 & 2 \\
Expressives & 57 & 18.75 & 3 \\
Commissives & 1 & 0.33 & 4 \\
Declaratives & 1 & 0.33 & 4 \\
\hline Total & $\mathbf{3 0 4}$ & $\mathbf{1 0 0}$ & \\
\hline
\end{tabular}

Assertive speech acts accounted for 51.97\%, ranking first with 158 out of 304 . Assertives were mostly the statements that commit the speaker to the truth of the proposed statement, such as asserting one's identity (e.g. "It's Mika, Lola.") and state of things (e.g. "He would always be a baby."). This is in accordance with Schlager's (1978) theory about the association of assertives with humor (e.g. "The back dog smelled like rotten eggs.").

Directives came in second with $28.29 \%$, having a frequency of 86 . These were shown in statements like commands (e.g. "Proceed to the mouth of the street."), requests (e.g. "Do it for me, Bunsoy, please?"), and mere questions that are posed for another character to answer (e.g. "What is your name?").

Expressive speech acts ranked third, accounting for $18.75 \%$. Expressives mostly come in the form of exclamations (e.g "Hay naku!", but sometimes, they are sentiments that say what the speaker is feeling (e.g. "I could be a nurse."), excuses and apologies (e.g. "Sorry, Lola.") and thanks (e.g. "Thanks for the dress, Ninang.").

Both the commissive and declarative speech act categories have one each, accounting for $0.33 \%$, ranking fourth. The commissive statement was just a statement of promise (e.g. "I promised her I'd always read you a story."), while the declarative statement stated a change of state of belief (e.g. "I do not believe in magic anymore.").

Table 2. Illocutionary Speech Acts in the UP Anthology $N=242$

\begin{tabular}{cccc}
\hline Illocutionary Acts & Frequency & Percent & Rank \\
\hline Assertives & 138 & 55.79 & 1 \\
Directives & 80 & 33.06 & 2 \\
Expressives & 15 & 6.20 & 3 \\
Commissives & 11 & 4.55 & 4 \\
Declaratives & 5 & 2.07 & 5 \\
\hline Total & $\mathbf{2 4 2}$ & $\mathbf{1 0 0}$ & \\
\hline
\end{tabular}

Indonesian Journal of EFL and Linguistics, 4(1), 2019 
Frances Mae Serenio \& Cindy Velasquez

For the stories in the UP anthology, assertives accounted for 55.79\%, having a frequency of 135 out of 242, ranking first. Like in the first table, they consisted mostly of statements that assert one's identity (e.g. "My name is Tibo.") and present state of things (e.g. "It would make the danger greater for you and Mama."). There is also one assertive statement which validates Schlager's (1978) theory about the association of assertives with humor, (e.g. "Well, I can't be of much help here if I keep on eating.").

Directives ranked second, with 80 counts or $33.06 \%$. Like the first table, they were mostly direct commands (e.g. "Find a partner."), requests (e.g. "Can you please help me?"), excuses (e.g. 'I'm terribly sorry, Carding, but I'm in a hurry to go to the rally at EDSA to answer the call for help."), or questions prompting the hearer to answer (e.g. "Is this your father?").

Expressives still ranked third, with 15 counts or $6.20 \%$. Expressive statements were mainly exclamations of feelings (e.g. "Of course not!") and sentiments regarding the speaker's feelings, like apologies (e.g. "Sorry, Father.") and thanks (e.g. "Thanks for your concern.").

Commissives was still in fourth place, with 11 counts or $\% 4.55$, and declaratives at fifth place with 5 counts or $2.07 \%$. Commissives were mostly statements about the speaker committing himself or herself to a future action, like promises (e.g. "I promise to be a good boy if I get back on the ground unharmed."), and declaratives were mostly statements about a drastic change of state (e.g. "Papa is dead." which was used as a declaration about the sudden death of the father).

Table 3. Types of Illocutionary Acts in all ten short stories $N=549$

\begin{tabular}{cccc}
\hline Illocutionary Acts & Frequency & Percent & Rank \\
\hline Assertives & 293 & 53.37 & 1 \\
Directives & 166 & 30.24 & 2 \\
Expressives & 72 & 13.11 & 3 \\
Commissives & 12 & 2.19 & 4 \\
Declaratives & 6 & 1.09 & 5 \\
\hline Total & $\mathbf{5 4 9}$ & $\mathbf{1 0 0}$ & \\
\hline
\end{tabular}

Summarized in Table 3 were the types of illocutionary acts that were most prevalent in all of the selected children's short stories from the two sources. These illocutionary acts were ranked according to which category has the highest percentage.

Assertives or statement of facts accounted for $53.37 \%$ of all speech acts produced (293 out of 549), followed by directives which accounted for 30.24\% (166 out of 
549), with expressive or affectives accounting for $13.11 \%$ (72 out of 549), commissives accounted for $2.19 \%$ (12 out of 549), and declaratives accounted for $1.09 \%$ (6 out of 549). The proportion of assertive speech acts within the short stories was considerably higher than all other speech act categories.

\section{DISCUSSION}

The speech act structure observed didactic role. Furthermore, it was found to be primarily informational, assertive, and expressive in nature. In the stories, some of the values that the writers aimed to teach the readers are nationalism (e.g. "To end this presentation, I'd like to say that knowing our history and attending flag ceremonies are good ways of showing our love for our country, but there are other ways of showing our love for our country, but there are other ways too."), love and pride for parents and siblings (e.g. "Nanay is the best caregiver." and "Tinuy is not a baby. He's your kuya."), and appreciation for education (e.g. "My mother said that studying is very important.").

The second highest in the results were directives. This supports the fact that reading a children's short story is like a parent communicating to his or her child. This is a confirmation that the Filipino writers can truly communicate with Filipino children and fulfill the didactic role - just like with assertives, they can convey and teach their message in a straightforward way without any risk of miscommunication and misunderstanding on the reader's part.

Moreover, one of the main functions of children's literature is to exhibit several stages of development, usually based on the protagonist behavior (Schlager, 1978). It appears that this function is mostly accomplished by using assertives where one is stating a fact that was true at some point in time (e.g. "When I was little, I like to put a towel over my head and stand in front of the mirror to I could pretend I had long, beautiful hair."). Finally, compared to the other speech acts, assertives were also the most frequently associated with humorous statements (e.g. "You don't run around all day in the sun and come out looking like a roasted sea urchin."), providing additional evidence that assertives are the most important speech acts in children's literature because they directly state things to children without the risk of being misunderstood. Children, after all, have the personality of being frank and honest themselves.

\section{CONCLUSION}

Essentially, it is useful to analyze literary pieces in terms of linguistic terms. This helps in delimiting possible interpretations of literary text, as literature is very subjective. Language, overall, needs deep and thorough understanding of its various fields in order to recognize its importance.

The application of a linguistic theory proved to be very helpful in analyzing a certain genre of literature. As literature is a manifestation of language in written medium, it 
Frances Mae Serenio \& Cindy Velasquez

is appropriate for a linguist to study the use of written language in the form of dialogues and utterances in text. Delving into the study gives an utmost understanding on how literature is presented.

Children's literature may be one of the most difficult genres to write, if not the most difficult. The writer has to take into consideration his or her aims in writing the story while focusing on other literary elements such as the theme and the plot at the same time. Not only that, the writer has to put in mind what kind of reaction he or she wants from his or her reader - whether it be amusement, rejection or wholesome acceptance through learning.

The Speech Act theories of Austin (1962) and Searle (1969) proved to be helpful in analyzing one of the genres of literature: fiction. In determining the kinds of speech acts employed by each dialogue, the researchers have managed to establish an able connection between the two fields. The speech acts, with their respective categories (asserting facts, directing commands and actions, expressing emotions, committing to a specific state and declaring a change of state), reveal the approaches that critics employ in order to study children's literature, and the reasons why writers aim to venture into writing children's literature, particularly short stories. The three approaches all serve as the guide for both linguists and literary critics in studying not only children's literature but also other forms of literary work as well. Overall, this study is all but one great realization of how amazingly versatile language study can be.

\section{REFERENCES}

Austin, J. L. (1962). How to Do Things with Words. Clarendon: Oxford.

Bucciarelli, M., Livia, C., and Bruno, B. (2002, September). How children comprehend speech acts and communicative gestures. Retrieved December 5, 2008 from the World Wide http://www.sciencedirect.com/science?_ob=ArticleURL\&_udi=B6VCW46SG3VG-

$3 \& \_u s e r=10 \& \_r d o c=1 \& \_f m t=\& \_o r i g=$ search $\& \_s o r t=d \& v i e w=c \& \_a c c t=C 0000$

$50221 \&$ _version $=1 \&$ _urlVersion $=0 \&$ _userid $=10 \& \mathrm{md} 5=5$ caee $1 \mathrm{~b} 233 \mathrm{a} 1261 \mathrm{f} 6235$ $634 \mathrm{c} 224 \mathrm{bf0e0}$

Hermosa, E (Ed.). (2001). Filipino Stories For Filipino Children: An Anthology from the UP Integrated School Creative Writing Classes. Manila: University of the Philippines Press.

Henderson, G. and Brown, C. (1997). Glossary of Literary Theory. Retrieved December 28 , 2008

from http://www.library.utoronto.ca/utel/glossary/Speech_act_theory.html/

Landa, J. (2007). Speech Acts in Literature: A Review of J. Hillis Miller's Work. $\begin{array}{llll}\text { Retrieved January } & 10, & 2009 & \text { from }\end{array}$ http://papers.ssrn.com/sol3/papers.cfm?abstract_id=1032448 
Miller, H. (2006, September). Literature as Conduct: Speech Acts in Henry James. Retrieved December 5, 2008 from the World Wide Web: http://www.atlantisjournal.org/Papers/28_2/HSussman.pdf/

Reeder, K. (1988). Children's speech act comprehension strategies and early literacy experiences. Retrieved January 10, 2009 from http://fla.sagepub.com/cgi/content/abstract/8/22/29/

Searle, J. (1969). Speech Acts: An Essay in the Philosophy of Language. United Kingdom: Cambridge University Press.

Schlager, N. (1978). Predicting children's choices in literature: A development approach. Children literature in education, Vol. 9 (3), 136-142.

Selden, R (Ed.). (2005). Literary Criticism Volume VIII from Formalism to Poststructuralism. New York: Cambridge University Press. 